\title{
Kandungan Antioksidan dan Kolesterol Dalam Daging Broiler (Galus gallus Domestica) Hasil Pemberian Suplemen dalam Pakan Dari Tepung Daun Pegagan dan Bayam Merah
}

\section{The Content of Antioxidants and Cholesterol in Broiler (Galus gallus Domestica) Meat Result of Supplements in The Feed of Flour from Pegagan and Red Spinach Leaf}

\author{
Muhammad Adnan Jafar Alfian ${ }^{1}$, Sunarno ${ }^{2 *}$, Muhamad Fikri Zulfikar ${ }^{1}$, Ahmad Rifa'i ${ }^{1}$ \\ ${ }^{1)}$ Program Studi Biologi, Departemen Biologi, Fakultas Sains dan Matematika, Universitas Diponegoro \\ ${ }^{2)}$ Departemen Biologi, Fakultas Sains dan Matematika, Universitas Diponegoro \\ Jl. Prof. Soedarto, SH, Tembalang, Semarang \\ *Email : sunzen07@gmail.com
}

Diterima 8 Januari 2018 / Disetujui 30 Januari 2018

\begin{abstract}
ABSTRAK
Daun pegagan dan bayam merah mengandung senyawa antioksidan (polifenol), kaya akan serat, vitamin dan mineral yang diharapkan dapat meningkatkan kandungan antioksidan dan menurunkan kandungaan kolesterol dalam daging broiler. Penelitian ini bertujuan untuk mengkaji dan menganalisa efek suplemen dari daun pegagan dan bayam merah terhadap kandungan antioksidan dan kolesterol daging. Metode yang digunakan dalam penelitian ini adalah rancangan acak lengkap yang terdiri atas 6 perlakuan dengan 3 kali ulangan. Enam perlakuan tersebut, meliputi P0 atau kontrol (broiler yang diberi pakan tanpa suplemen tepung daun pegagan dan daun bayam merah), P1 (broiler yang diberi pakan dengan suplemen tepung daun pegagan sebanyak 5\%), P2 (broiler yang diberi pakan dengan suplemen tepung daun bayam merah sebanyak 5\%), P3, P4, dan P5 berturutturut adalah broiler yang diberi pakan dengan suplemen tepung kulit daun pegagan dan bayam merah dengan rasio (3,75\%:1,25\%, 2,5\%:2,5\% atau 1,25\%:3,75\%). Pemberian perlakuan di lakukan secara ad libitum setiap hari sebanyak 2 kali Perlakuan diberikan selama 35 hari. Hasil penelitian menunjukkan bahwa suplemen tepung daun pegagan dan daun bayam merah dalam pakan memberi pengaruh nyata terhadap bobot tubuh, kadar antioksidan dan kolesterol dalam daging broiler $(\mathrm{P}<0,05)$. Suplemen tepung daun pegagan dan bayam merah dengan rasio konsentrasi 2,5\%:2,5\% memberi pengaruh terbaik terhadap tiga parameter yang diamati sehingga hasil penelitian ini dapat diaplikasikan untuk mendukung kegiatan budidaya agar broiler dapat menghasilkan daging yang menyehatkan.
\end{abstract}

Kata kunci: broiler, daun pegagan, daun bayam merah, suplemen, kolesterol, antioksidan

\begin{abstract}
Leaf from the pegagan and red spinach contain antioxidant compounds (polyphenols), rich in fiber, vitamins, and minerals are expected to increase the content of antioxidants and lower cholesterol levels in broiler meat. This research aims to examine and analyze the effects of supplements of leaf pegagan and red spinach on antioxidant and cholesterol content of broiler meat. The method used in this study was a completely randomized design consisting of six treatments with three replications. The six treatments, including P0 or control (broilers fed without flour supplementation of pegagan leaf and red spinach), P1 (broilers fed with leaf flour supplements pegagan as much as 5\%), P2 (broilers fed with leaf flour supplements red spinach as much as 5\%), P3, P4, P5 respectively are broilers fed with supplements of pegagan leaf flour and red spinach leaf flour with rasio $((3,75 \%: 1,25 \%, 2,5 \%: 2,5 \%$ atau 1,25\%:3,75\%). Treatment was done on ad libitum twice daily. Treatment was given for 36 days. The result showed that leaf flour supplements of pegagan and red spinach in the feed influence on body weight, antioxidant levels, and cholesterol in broiler meat $(\mathrm{P}<0,05)$. Leaf flour supplements of pegagan and red spinachwith a concentration ratio of 2,5\%:2,5\% the best influence on the three parameters observed so that the results of this study can be applied to support activities so that the broiler can produce healthy meat.
\end{abstract}




\section{PENDAHULUAN}

Sektor perunggasan terutama ayam ras atau broiler masih menjadi prioritas utama untuk memenuhi kebutuhan protein hewani masyarakat. Broiler memiliki beberapa kelebihan dibandingkan dengan hewan lainnya, antara lain menghasilkan daging dengan kandungan gizi yang tinggi, pertumbuhan cepat, dan memiliki tingkat konversi pakan menjadi daging yang tinggi. Ayam broiler memiliki potensi yang cukup besar untuk dibudidayakan dalam rangka mencukupi kebutuhan protein hewani masyarakat. Data dari tahun 2005 sampai 2017 menunjukkan bahwa permintaan daging unggas, terutama broiler terus mengalami peningkatan. Permintaan daging broiler oleh masyarakat meningkat $65 \%$ menjadi 2.136 .600 ton per tahun (Dirjen P2HP, 2017).

Permasalahan kesehatan yang berkaitan dengan konsumsi daging ayam broiler selalu terkait dengan kandugan asam lemak tidak jenuh yang tinggi. Gangguan kesehatan yang muncul akibat konsumsi asam lemak tidak jenuh dipengaruhi oleh tiga hal, yaitu jumlah, jenis, dan kondisi asam lemak tersebut. Senyawa ini telah diketahui bersifat rentan terhadap oksidasi. Peroksidasi asam lemak dapat menghasilkan radikal bebas dan memicu rantai reaksi radikal bebas yang berdampak munculnya berbagai macam penyakit degenerasi, seperti jantung koroner, hipertensi, stroke, dan lain-lain. Kondisi ini dapat dicegah dengan pemberian bahan yang mengandung antioksidan dan serat (Isti, 2010).

Penelitian tentang penggunaan bahan tanaman untuk menurunkan kolesterol dan meningkatkan kandungan antioksidan dalam tubuh telah banyak dilaporkan. Dong et al. (2007) melaporkan bahwa pemberian polysavon (ekstrak alfafa) yang merupakan senyawa sejenis saponin efektif mengurangi deposisi lemak abdominal dan kandungan antioksidan dalam tubuh tanpa berpengaruh negatif terhadap performa ayam broiler. Sementara itu An et al (2001) menyatakan bahwa fosfolipida ekstrak safflower yang mengandung kelompok senyawa fenol dapat menurunkan kadar trigliserida hati dan kolesterol serum dan meningkatkan antioksidan tanpa adanya efek yang merugikan terhadap ayam broiler (finisher). Viveros et al (2007) juga melaporkan bahwa penggunaan biji lupin (Lupinus albus) pada ayam broiler dapat menurunkan bobot badan, konsumsi ransum, meningkatkan antioksidan serta menurunkan kolesterol. Kandungan asam lemak tak jenuh yang tinggi pada daging ayam broiler menyebabkan konsumen membatasi konsumsi daging ini, sehingga diperlukan adanya penekan asam lemak tak jenuh dengan tanaman yang kaya akan antioksidan seperti tumbuhan pegagan dan bayam merah.

Pegagan yang dikenal dengan nama ilmiah C. asiatica memiliki banyak manfaat yaitu dapat menurunkan kadar kolesterol dan meningkatkan kandungan antioksidan dalam tubuh. Bukti penelitian telah menunjukkan bahwa ekstrak etanol dari C. asiatica dapat menurunkan kadar kolesterol pada hewan model puyuh dan hamster hiperkolesterolemia mencapai $79 \%$ dan penurunan trigliserida mencapai 95\%. Selain dapat menurunkan kadar kolesterol atau trigliserida, pegagan juga memiliki aktivitas antioksidan (Pitella et al., 2009). Pegagan (C. asiatica) mengandung berbagai macam senyawa aktif, antara lain asiaticoside, asiatic acid, madecassoside, madecassic acid dan brahmoside (Annisa, 2006). Januwati dan Yusron (2005) menyatakan bahwa tanaman C. asiatica diketahui memiliki kandungan minyak atsiri, seperti sitronelal, linalool, neral, menthol dan linalil asetat. Kandungan kimia pegagan terbagi menjadi beberapa golongan, yaitu asam amino, flavonoid, terpenoid, dan minyak atsiri (Dalimartha, 2006). Senyawa-senyawa tersebut berfungsi sebagai antioksidan yang sangat bermanfaat bagi kesehatan tubuh.

Bayam merah dikenal sebagai tanaman sayuran yang banyak mengandung serat kasar, vitamin, mineral, dan juga kaya antioksidan, seperti flavonoid dan licopen. $\mathrm{Uji}$ in vivo pemberian bayam merah pada 120 ekor DOC broiler strain Lohmann membuktikan bahwa 5\% penambahan bayam merah pada pakan yang diberikan selama 35 hari tidak nyata mempengaruhi performan ayam, namun nyata dapat menghambat terjadinya peroksidasi lipid pada daging dada dan hati ayam broiler (Isti, 2010). Bayam merah mengandung banyak 
fitokimia yang berguna untuk mengurangi dampak kerusakan tubuh akibat radikal bebas. Sumber warna merah bermanfaat untuk mencegah masalah prostat, dan memelihara kesehatan tubuh (Rumimper et al., 2014).

Berdasarkan potensi dan bukti-bukti penelitian tersebut menunjukkan bahwa daun pegagan dan daun bayam merah dapat dimanfaatkan sebagai suplemen pakan untuk menurunkan kadar kolesterol dan meningkatkan antioksidan daging broiler. Oleh karena itu penelitian telah membuktikan tentang pemanfaatan kedua bahan tersebut terhadap bobot tubuh, kandungan kolesterol dan antioksidan di dalam daging broiler.

\section{METODE PENELITIAN}

\section{Hewan Uji}

Hewan uji yang digunakan dalam penelitian ini adalah ayam broiler (Gallus gallus domestica) dengan jumlah 18 ekor yang dibagi ke dalam 6 kelompok perlakuan dengan 3 kali ulangan. Broiler dipelihara selama 35 hari dan divaksin sebanyak tiga kali. Vaksin NDI (Newcastle desease I) dilakukan pada saat DOC berumur 3 hari melaui tetes mata, vaksin gumboro dilakukan pada saat umur 10 hari melalui air minum dan vaksin ND II pada saat ayam berumur 21 hari melalui air minum. Pencegahan stres akibat vaksinasi, faktor lingkungan dan saat penimbangan dengan cara diberi vitamin yaitu Vita Stres melalui air minum.

\section{Prosedur Penelitian}

Prosedur penelitian diawali dengan koleksi, pengeringan bahan uji, dan pembuatan tepung dari daun pegagan dan daun bayam merah. Bagian daun pegagan dan daun bayam merah dikoleksi dari wilayah Semarang. Bahan-bahan tersebut secara terpisah dipotong-potong sekitar $3 \mathrm{~cm}$, dicuci, ditiriskan, dan selanjutnya dikeringkan anginkan selama 2 hari di bawah sinar matahari dan selanjutnya dioven pada suhu $60^{\circ} \mathrm{C}$ selama 30 36 jam sampai diperoleh bahan kering dengan kadar air $10 \%$. Daun pegagan dan daun bayam merah kering lalu digiling dan diperoleh tepung daun pegagan dan tepung daun bayam merah. Tepung disimpan di dalam boks plastik dan siap untuk digunakan.

Tahap selanjutnya adalah pembuatan pakan bersuplemen tepung daun pegagan dan daun bayam merah. Pakan bersuplemen untuk broiler dibuat dengan cara menambahkan tepung dari kedua bahan tersebut (baik secara terpisah/kombinasi) ke dalam pakan broiler sesuai persentase yang dibutuhkan (kadar sesuai formula). Tepung daun pegagan atau bayam merah yang telah ditentukan beratnya dicampur dengan pakan broiler yang telah ditimbang sesuai kebutuhan. Pakan yang telah tercampur dengan bahan suplemen kemudian diaduk-aduk sampai homogen, dimasukkan ke dalam tempat pakan dalam kandang broiler. Pakan bersuplemen diberikan secara ad libitum setiap pagi jam 07.00 dan sore jam 16.00.

Tahap penelitian dilanjutkan dengan penyiapan kandang broiler. Tempat pakan dan minum ditempatkan menyatu dengan kandang. Penempatan diluar kandang untuk menghindari pakan yang terbuang dan mengurangi pakan atau minum yang kotor karena tercampur oleh kotoran broiler. Setelah penyiapan kandang broiler, kemudian dilakukan penyiapan dan aklimasi hewan uji. Hewan uji yang digunakan dalam penelitian ini adalah broiler (Gallus gallus domestica). Sebelum aklimasi, dilakukan pemilihan hewan uji, yaitu memilih bibit yang baik dengan bobot yang relatif sama, bebas penyakit, dan normal. Selanjutnya, dilakukan aklimasi selama 7 hari. Selama aklimasi, hewan uji diberi pakan dan minum secara ad libitum.

Hewan uji yang sudah diaklimasi kemudian diberi perlakuan. Pakan bersuplemen tepung daun pegagan dan daun bayam merah diberikan pada broiler setelah aklimasi yaitu pada umur 15 hari sampai umur 35 hari. Sebelum dimasukkan ke dalam kandang, DOC ditimbang terlebih dahulu untuk mengetahui bobot hidup awal. Satu kandang membutuhkan satu tempat pakan, satu tempat air minum, dan bola lampu 60 watt yang berfungsi sebagai penerang dan pemanas. Ada enam perlakuan yang diberikan pada hewan uji, P0 atau kontrol (broiler yang diberi pakan tanpa suplemen tepung daun pegagan dan daun bayam merah), P1 
(broiler yang diberi pakan dengan suplemen tepung daun pegagan sebanyak 5\%), P2 (broiler yang diberi pakan dengan suplemen tepung daun bayam merah sebanyak 5\%), P3, P4, dan P5 berturut-turut adalah broiler yang diberi pakan dengan suplemen tepung kulit daun pegagan dan bayam merah dengan rasio $(3,75 \%: 1,25 \%$, 2,5\%:2,5\% atau 1,25\%:3,75\%). Pakan diberikan diberikan secara ad libitum 2 kali sehari yaitu pagi jam 07.00 dan sore jam16.00. Setiap hari dilakukan pengukuran temperatur dan kelembapan ruangan selama berlangsungnya penelitian. Di akhir perlakuan dilakukan penimbangan bobot tubuh broiler dengan menggunakan timbangan digital. Pengukuran kadar kolesterol daging broier dengan menggunakan metode seperti yang dilakukan oleh Ariyani (2006), sedangkan kadar antioksidan dengan menggunakan metode seperti yang dilakukan oleh Nahariah et al. (2014).

\section{Analisis dan Interpretasi Data}

Data yang diperoleh, meliputi bobot tubuh akhir, kadar kolesterol dan antioksidan daging broiler diuji pola distribusi dan homogenitasnya, dan dilanjutkan dengan uji Analysis of Varian (ANOVA). Uji lanjut terhadap variabel bobot tubuh menggunakan Duncant Multi Range Test (DMRT) sedangkan untuk variabel kadar kolesterol dan kadar antioksidan menggunakan Beda Nyata Terkecil (Least Significant Differences), masing-masing dengan taraf kepercayaan $95 \%$.

\section{HASIL DAN PEMBAHASAN}

Data hasil penelitian yang meliputi bobot tubuh, kadar kolesterol dan antioksidan total daging broiler ditunjukkan pada Tabel 1. Data pada Tabel 1 menunjukkan bahwa suplemen tepung daun pegagan (Centella asiatica) dan tepung daun bayam merah (Alternanthera amoena Voss) yang diberikan dalam pakan tidak berpengaruh nyata $(\mathrm{P}<0,05)$ terhadap bobot tubuh namun memberi pengaruh nyata terhadap kadar kolesterol dan antioksidan daging femur broiler.

Data seperti pada Tabel 1 menunjukkan bahwa bobot tubuh broiler antara yang mendapatkan suplemen tepung daun pegagan atau bayam merah tidak berbeda nyata dengan kontrol. Hal ini berarti bahwa pemberian suplemen tepung daun pegagan dan bayam merah tidak mempengaruhi absorbsi bahan baku metabolisme atau nutrisi hasil pencernaan makanan di dalam usus halus sehingga akhirya tidak berpengaruh terhadap penurunan bobot tubuh. Faktor utama yang mempengaruhi pertumbuhan broiler adalah kandungan protein, energi, dan imbangan nutrisi dalam pakan yang dikonsumsi. Jumlah konsumsi energi dan protein selama masa pemeliharaan pada masing-masing perlakuan bersumber dari pakan dengan komposisi nutrisi dan jumlah yang sama. Bobot tubuh broiler dipengaruhi oleh konsumsi pakan, konsumsi energy, protein, dan profil nutrisi pakan (Leeson and Summers, 2008).

Tabel 1. Bobot tubuh, kadar kolesterol, dan antioksidan total daging broiler setelah perlakuan pakan dengan suplementasi tepung daun pegagan dan daun bayam merah

\begin{tabular}{lcccccc}
\hline \multirow{2}{*}{ Parameter } & \multicolumn{5}{c}{ Perlakuan } \\
\cline { 2 - 7 } & P0 & P1 & P2 & P3 & P4 & P5 \\
\hline $\begin{array}{l}\text { Bobot tubuh akhir }(\mathrm{kg}) \\
\begin{array}{l}\text { Antioksidan total daging femur } \\
(\mu \mathrm{g} / \mathrm{g})\end{array}\end{array}$ & $1,434^{\mathrm{a}}$ & $1,213^{\mathrm{a}}$ & $1,254^{\mathrm{a}}$ & $1,015^{\mathrm{a}}$ & $1,126^{\mathrm{a}}$ & $1,216^{\mathrm{a}}$ \\
$\begin{array}{l}\text { Kolesterol total daging femur } \\
(\mathrm{mg} / 100 \mathrm{~g})\end{array}$ & $3,76^{\mathrm{a}}$ & $16.03^{\mathrm{b}}$ & $4,02^{\mathrm{b}}$ & $4,25^{\mathrm{b}}$ & $6,68^{\mathrm{c}}$ & $4,56^{\mathrm{b}}$ \\
\hline
\end{tabular}

Keterangan: P0: kontrol (pakan tanpa suplementasi tepung daun pegagan dan bayam merah), P1 dan P2, berturut-turut pakan dengan suplementasi tepung daun pegagan atau bayam merah masing-masing 5\%, P3, P4, dan P5 adalah pakan dengan suplementasi tepung daun pegagan dan daun bayam merah dengan rasio berturutturut, $3,75 \%: 1,25 \%, 2,5 \%: 2,5 \%$, dan 1,25\%:3,75\%. 
Pengaruh pemberian suplemen tepung daun pegagan dan atau daun bayam merah terhadap kadar kolesterol dalam daging femur broiler dapat dilihat pada Tabel 1. Hasil analisis Anova pada signifikansi 5\% menunjukkan bahwa pemberian suplemen daun pegagan, daun bayam merah atau kombinasi berpengaruh nyata terhadap kadar kolesterol daging broiler $(\mathrm{P}<0,05)$. Analisis lebih lanjut dengan BNT pada signifikansi 5\% menunjukkan bahwa kadar kolesterol P1, P2, P3, P4, dan P5 berbeda nyata dengan kontrol. Analisis selanjutnya menunjukkan bahwa P4 berbeda nyata dengan kontrol dan perlakuan lainnya. Hasil penelitian ini menunjukkan bahwa pemberian suplemen tepung dari daun pegagan, bayam merah atau kombinasinya dapat menurunkan kadar kolesterol dalam daging broiler. Berturut-turut kadar kolesterol pada perlakuan P1 sampai dengan P5 adalah 138,98; 136,12; 139,04; 102,24; dan $139,14 \mathrm{mg} / 100 \mathrm{~g}$. Kadar kolesterol daging femur broiler paling rendah terdapat pada perlakuan P4 yaitu suplemen tepung kombinasi antara daun pegagan dengan kolesterol dengan rasio 2,5\%:2,5\%. Berdasarkan data tersebut dapat dinyatakan bahwa kadar kolesterol dalam daging femur broiler dapat diturunkan dengan memanfaatkan bahan-bahan alami, terutama yang berasal dari tumbuh-tumbuhan yang mengandung antioksidan (Santi, 2015).

Penurunan kadar kolesterol dalam daging femur broiler disebabkan karena kandungan senyawa polifenol yang terdapat pada suplemen tepung daun pegagan dan bayam merah. Mekanisme penurunan kolesterol oleh senyawa polifenol terjadi melalui penghambatan secara langsung aktivitas enzim HMG-KoA (3-hidroksi 3-metilglutaril koenzim-A) redukatse oleh senyawa fenol. Penghambatan aktivitas enzim ini menyebabkan tidak terbentuknya mevalonat dari HMG-KoA, dimana mevalonat ini akan diubah menjadi skualen, lanosterol, dehidrolanosterol, D8-dimetilsterol, 7-dehidrokolesterol, dan akhirnya menjadi kolesterol. Senyawa fenol merupakan antioksidan yang dapat mencegah oksidasi lipid dan menghambat kerja enzim HMG-KoA reduktase dalam pembentukan mevalonat, sehingga sintesis kolesterol terganggu (Eisenbrand, 2005). Pembentukan kolesterol terjadi melalui beberapa tahapan, salah satunya adalah pebentukan mevalonat dari asetil-KoA. Hasil penelitian Syahruddin et al (2011) menyatakan bahwa kandungan polifenol dalam bahan pakan yang terkonsumsi dapat menghasilkan kadar kolesterol daging yang rendah. Polifenol merupakan jenis antioksidan alami yang terdapat di dalam daun pegagan atau bayam merah yang merupakan komponen aktif dalam menurnkan kadar kolesterol dalam daging broiler. Perlakuan P4 yaitu suplemen tepung yang merupakan kombinasi daun pegagan dengan bayam merah pada rasio 2,5\%:2,5\% memberi pengaruh terhadap kadar kolesterol daging paling rendah, yaitu sebesar 102,24 mg/100g.

Kadar antioksidan total dalam daging femur broiler umur 35 hari yang diberi suplemen tepung daun pegagan dan daun bayam merah selama 21 hari (umur 2 sampai 5 minggu) dapat dilihat pada Tabel 1. Pemberian suplemen tepung daun pegagan dan daun bayam merah memberi pengaruh nyata $(\mathrm{P}<0,05)$ terhadap kadar antioksidan total dalam daging femur broiler. Analisis lebih lanjut menggunakan uji BNT signifikansi 5\% menunjukkan bahwa kadar antioksidan total daging femur antara P1, P2, P3, $\mathrm{P} 4$, dan $\mathrm{P} 5$ berbeda nyata dengan kontrol, antara P1, P2, P3, dan P5 tidak berbeda nyata namun semuanya berbeda nyata dengan P4. Bukti ini menunjukkan bahwa suplemen tepung kombinasi antara daun pegagan dengan bayam merah pada rasion 2,5\%:2,5\% dapat meningkatkan kadar antioksidan total yaitu $6,68 \mu \mathrm{g} / \mathrm{g}$ dalam daging femur broiler demikian pula perlakuan suplemen lainnya. P1, P2, P3, dan P5 memberi pengaruh pada peningkatan antioksidan total dalam daging broiler lebih tinggi dibanding kontrol, berturutturut 16,$03 ; 4,02 ; 4,25 ;$ dan $4,56 \mu \mathrm{g} / \mathrm{g}$.

Kadar antioksidan total daging femur broiler yang diberi perlakuan suplemen lebih tinggi dibanding kontrol. Peningkatan antioksidan tersebut dapat disebabkan karena kandungan senyawa polifenol dari tepung daun pegagan atau bayam merah yang terdistribusi ke dalam daging femur yang berfungsi untuk memelihara integritas dan fungsi jaringan. Senyawa polifenol/fenol merupakan suatu senyawa yang mengandung gugus hidroksil yang terikat langsung pada gugus 
cincin hidrokarbon aromatik. Senyawa polifenol yang terdapat pada tumbuhan, seperti halnya pada daun pegagan dan bayam merah yaitu fenol sederhana yang meliputi benzonquinone, asam fenolat, asetofenon, naftokuinon, xanton, bioflavonoid kumarin, stilben, turunan tirosin, asam hidroksi sinamat, flavonoid, lignin, dan tannin (Dhianawaty dan Ruslin, 2015). Berbagai macam senyawa polifenol yang terkandung dalam kedua bahan suplemen tersebut merupakan sumber antioksidan yang dapat memperbaiki status kesehatan pada broiler (Lee et al., 2010). Senyawa polifenol merupakan antioksidan alami yang dapat melindungi komponen seluler dari kerusakan biologis akibat radikal bebas ( $\mathrm{Su}$ et al., 2007). Velasco and Williams (2011) menyatakan, antioksidan yang berasal dari tumbuh-tumbuhan sangat baik dalam meningkatkan kualitas daging karena dapat menghambat atau mencegah kerusakan akibat dampak dari radikal bebas. Polifenol dapat berperan secara langsung dalam menangkap radikal bebas di dalam tubuh. Sebagai antioksidan, senyawa polifenol dari daun pegagan dan bayam merah dapat menurunkan peroksidasi lemak dan meningkatkan kualitas daging. Peningkatan antioksidan dapat menurunkan kadar radikal bebas dan total saturated fatty acids (SFA) serta meningkatkan poly unsaturated fatty acids (PUFA) daging sehingga meningkatkan stabilitas oksidasi daging femur broiler yang akhirnya akan meningkatkan kualitas daging (Fassah et al., 2012). Tingginya kandungan antioksidan daging femur broiler seperti pada penelitian ini akan meningkatkan nilai nutrisi dari daging tersebut sehingga meningkatkan kesehatan bagi yang mengonsumsinya.

\section{KESIMPULAN}

Suplemen tepung dari daun pegagan dan bayam merah dapat meningkatkan bobot tubuh, meningkatkan kadar antioksidan dan menurunkan kadar kolesterol daging broiler. Suplemen tepung kombinasi daun pegagan dan bayam merah dengan rasio konsentrasi 2,5\%:2,5\% memberi pengaruh terbaik terhadap bobot tubuh, kadar antioksidan dan kolesterol sehingga dapat diaplikasikan pada budidaya broiler untuk meningkatkan nilai nutrisi sehingga dapat meningkatkan kesehatan bagi konsumen.

\section{DAFTAR PUSTAKA}

An, B. K., Nishiyama, H., Tanaka, K., Ohtani, S., Iwata, T., Tsutsumi, K and M. Kasai. 2001. Dietary saffl ower phospholipid reduces liver lipids in laying hens. Poult. Sci, 76:689-695

Annisa, R. F. 2006. Pengaruh pemberian ekstrak air daun pegagan (Centella asiatica) terhadap kemampuan kognitif dan kadar neurotransmiter monoamin pada hipokampus puyuh (Rattus norvegicus L) galur Wistar jantan dewasa. Skripsi Sarjana Biologi, Institut Teknologi Bandung, Bandung

Ariyani, E. 2006. Penetapan Kandungan Kolesterol dalam Kuning Telur pada Ayam Petelur. Balai Penelitian Ternak, Pusat Penelitian dan Pengembangan Peternakan, pp. $12-15$

Dalimartha S. 2006. Atlas Tumbuhan Obat Indonesia. Jakarta : Puspa Swara.

Dhianawaty, D dan Ruslin. 2015. Kandungan total polifenol dan aktivitas antioksidan dari ekstrak metanol akar Imperata cylindrica (L) Beauv. (alang-alang). MKB., 47(1): 6064

Dirjen P2HP: Direktorat Jendral Pengolahan dan Pemasaran Hasil Pertanian Kementrian Pertanian. 2017. Statistik ekspor impor komoditas pertanian 2005-2017. Jurnal Statistik Ekspor Impor Komoditas Pertanian, ISSN: 2337-9578

Dong, X. F., Gao, W. W., Tong, J. M., Jia, H. Q., Sa, R. N and Q. Zhang. 2007. Effect of polysavone (Alfalfa extract) on abdominal fat deposition and immunity in broiler chickens. Poult. Sci, 86:1955-1959

Eisenbrand, G. 2005. Toxicological Evaluation of Red Mold Rice. Mol. Nutr. Food Res, 50: 322-327.

Fassah DM, Supadmo, Rusmana. 2012. Efek pemberian ektrak limbah teh hitam sebagai 
sumber antioksidan dan level energi-protein pakan yang berbeda terhadap stabilitas oksidatif dan kualitas daging ayam broiler. Buletin Peternaka, 36 (2): 75-86.

Isti, A. 2010. Komparasi antioksidan extra the hijau kulit manggis dan kulit rambutan terhadap stabilitas oksidasi dan organoleptik daging ayam broiler, Lab. Nutrisi dan Makanan Ternak, Fakultas Peternakan, Universitas Negeri Sebelas Maret, Lab. Tanaman Pangan, Surakarta.

Januwati, M dan M. Yusron. 2005. Budidaya Tanaman Pegagan. Balai Penelitian Tanaman Obat dan Aromatika, Badan Penelitian dan Pengembangan Pertanian. Jakarta

Lee, C. X., Lee, B. D., Na, J. C and H. An. 2010. Carotenoid accumulation and their antioxidant activity in spent laying hends as affected by polarity and feeding period. Asian-Aust. J Anim Sci, 23(6): 799-805.

Leeson, S and J. D. Summers. 2008. Commercial Poultry Nutrition.3rd Ed. Departement of Animal and Poultry Science, University Guelph.University Books. Canada.

Pittella, F., Dutra, R.C., Junior, D.D., Lopes, M.T. and Barbosa, N.R. 2009. Antioxidant and cytotoxic activities of Centella asiatica (L) Urb. Int J Mol Sci, 10(9), 3713-21.

Rumimper, E. A., Posangi, J dan J. Wuisan. 2014. Uji efek perasan daun bayam merah (Amaranthus tricolor) terhadap kadar hemoglobin pada tikus Wistar (Rattus norvegicus). Jurnal e-Biomedik, 2(2).

Santi, M. A. 2015. Produksi daging ayam broiler fungsional tinggi antioksidan dan rendah kolesterol melalui pemberian tepung pucuk Indigofera zollingerian. Thesis Sekolah Pascasarjana, Institut Pertanian Bogor, Bogor.

Su, L., Yin, J. J., Charles, D., Zhou, K., Moore, J and L. Yu. 2007. Total phenolic contents, chelating capacities, and radical-scavenging properties of black peppercorn, nutmeg rosehip, cinnamon and oregano leaf. Food Chemistry, 100: 990-997.
Syahruddin, E., Abbas, H., Purwati, E dan Y. Heryandi. 2011. Effect of fermented noni leaf (Morinda citrifolia L.) in diets on cholesterol content of broiler chicken carcass. JITV, 16(4): 266-271.

Velasco, V and P. Williams. 2011. Review: improving meat quality through natural antioxidants. Chilean Journal of Agricultural Research, 71(2) :313-322.

Viveros, A., Centeno, C., Arija, I and A. Brenes. 2007. Cholesterol-lowering effects of dietary lupin (Lupinus albus var Multolupa) in chicken diets. Poult. Sci, 86:2631-2638. 